\title{
PENGARUH HARGA KOMODITAS PANGAN TERHADAP INFLASI DI KOTA MALANG TAHUN 2011-2016 \\ Dicky Zunifar Rizaldy
}

BRI Life

Dickykiky@ rocketmail.com

\begin{abstract}
This research was proposed to know the effect of food commodity prices on inflation with a case study of onion and cayenne pepper commodity prices in Malang City since 2011 until 2016. The analytical method used was Partial Adjustment Model (PAM) and Clasical Assumption Test. The used data in this research was secondary data that got from various sources such as Central Bureau of Statistics (BPS) and Availability of Information System and Development of Basic Materials Prices (Siskaperbapo) East Java. The result of this research showed that result of the long run equation test PAM of onion had significant effect and cayenne had significant effect on inflation. On result of the short run equation test PAM of onion and cayenne pepper had significant effect on inflation in Malang City.
\end{abstract}

Keywords : Inflation, Onion Price, Cayenne Price.

\begin{abstract}
Abstrak
Penelitian ini bertujuan untuk mengetahui pengaruh harga komoditas pangan terhadap inflasi dengan studi kasus harga komoditas bawang merah dan cabe rawit di Kota Malang pada Tahun 2011 - 2016. Metode analisis yang digunakan adalah Partial Adjustment Model (PAM) dan Uji Asumsi Klasik. Data yang digunakan dalam penelitian ini adalah data sekunder yang diperoleh dari berbagai sumber antara lain BPS (Badan Pusat Statistik) dan Siskaperbapo Jawa Timur (Sistem Informasi Ketersediaan dan Perkembangan Harga Bahan Pokok). Hasil penelitian ini menunjukkan bahwa pada hasil uji persamaan jangka panjang PAM harga bawang merah berpengaruh signifikan dan harga cabe rawit berpengaruh signifikan terhadap besarnya inflasi. Sementara pada hasil uji persamaan jangka pendek PAM pengaruh harga bawang merah dan cabe rawit berpengaruh signifikan terhadap inflasi di Kota Malang.
\end{abstract}

Kata Kunci : Inflasi, Harga Bawang merah, Harga Cabe rawit.

\section{PENDAHULUAN}

Komoditas bahan pangan mempunyai peranan yang sangat penting dalam aspek ekonomi, sosial, dan politik (Prabowo, 2014). Harga komoditas bahan pangan sendiri sangat dipengaruhi oleh kestabilan distribusi permintaan dan penawaran. Harga komoditas sering mengalami fluktuasi dikarenakan oleh beberapa 
faktor yaitu, produksi bahan pokok mengalami gagal panen akibat cuaca, gangguan hama serta faktor perkembangan harga bahan pokok akan mengganggu jalannya distribusi.

Di Indonesia harga komoditas bahan pangan yang sering mengalami fluktuasi harga antara lain beras, jagung, kedelai tepung terigu, gula pasir, minyak goreng, bawang merah, cabe,telur, daging dan susu (Sumaryanto, 2009). Perubahan harga komoditas bahan pangan dapat menjadi penyumbang terbesar laju inflasi dikarenakan dengan jumlah penduduk yang cukup besar, permintaan bahan makanan akan menjadi cukup tinggi. Namun terkadang penawaran belum cukup mampu untuk memenuhi permintaan tersebut, sehingga akhirnya mendorong laju inflasi (Santoso, 2011).

Inflasi merupakan salah satu permasalahan perekonomian yang sering terjadi di Indonesia. Inflasi diartikan sebagai kenaikan harga secara umum dan terus-menerus. Dapat dikatakan terjadi inflasi apabila kenaikan harga tersebut juga mempengaruhi kenaikan harga barang-barang lainnya. Pergerakan harga komoditas dapat dijadikan sebagai leading indicators inflasi. Alasannya adalah, yang pertama yaitu, harga komoditas mampu merespon secara cepat shock yang terjadi dalam perekonomian secara umum, seperti peningkatan permintaan (aggregate demand shock). Kedua, harga komoditas juga mampu merespon terhadap noneconomic shocks, seperti: banjir, tanah longsor dan bencana alam lainnya yang menghambat jalur distribusi dari komoditas tersebut.

Kota Malang merupakan kota kedua terbesar di Jawa Timur dengan jumlah penduduk 861.414 jiwa. Kota Malang memiliki letak yang sangat strategis berada diantara Kota Batu dan Kabupaten Malang menjadikan Kota Malang sebagai pusat perdagangan dan jasa komersil untuk daerah di sekitarnya. Saat ini lahan pertanian di Kota Malang tersisa 865 Hektare yang tersebar di wilayah Kecamatan Blimbing, Kedung kandang, Sukun dan Lowokwaru (Kementerian Pertanian, 2015).

Berkurangnya lahan pertanian di Kota Malang disebabkan oleh alih fungsi lahan persawahan menjadi perumahan. Keterbatasan lahan 
pertanian mengakibatkan Kota Malang tidak bisa mencukupi kebutuhan bahan pangan sendiri, sehingga bergantung pada kota lain penghasil bahan pangan seperti Kota Batu dan Kabupaten Malang. Tingginya permintaan terhadap bahan pangan relatif dengan ketersediaannya akan menciptakan kejutan harga yang cenderung naik yang nantinya akan berpengaruh terhadap besarnya inflasi.

Berdasarkan data yang diperoleh dari Badan Pusat Statistik (BPS) Kota Malang dapat terlihat persentase inflasi Kota Malang tahun 2011 sebesar 4,05 persen dan menduduki urutan ke-4 dari 10 kota IHK di Jawa Timur, sedangkan pada tahun 2015, persentase inflasi tahunan Kota Malang sebesar 3,32 persen dan menduduki urutan ke-2 dari 10 kota IHK di Jawa Timur. Sepuluh komoditas bahan pangan yang turut berpengaruh dalam besarnya inflasi di tahun 2015 antara lain: cabe merah, bawang merah, beras, telur ayam ras, angkutan udara, cabe rawit, daging ayam ras, bawang putih, tarif listrik dan daging sapi.

Berdasarkan gambar 1. di bawah ini, bahwa harga komoditas pangan mempunyai pengaruh terhadap besarnya inflasi di Kota Malang. Hal tersebut melatarbelakangi penelitian ini dan bertujuan untuk mengetahui seberapa besar pengaruh harga komoditas bawang merah dan cabe rawit terhadap inflasi di Kota Malang pada jangka panjang dan jangka pendek.

\section{Gambar 1. Inflasi Kota Malang}

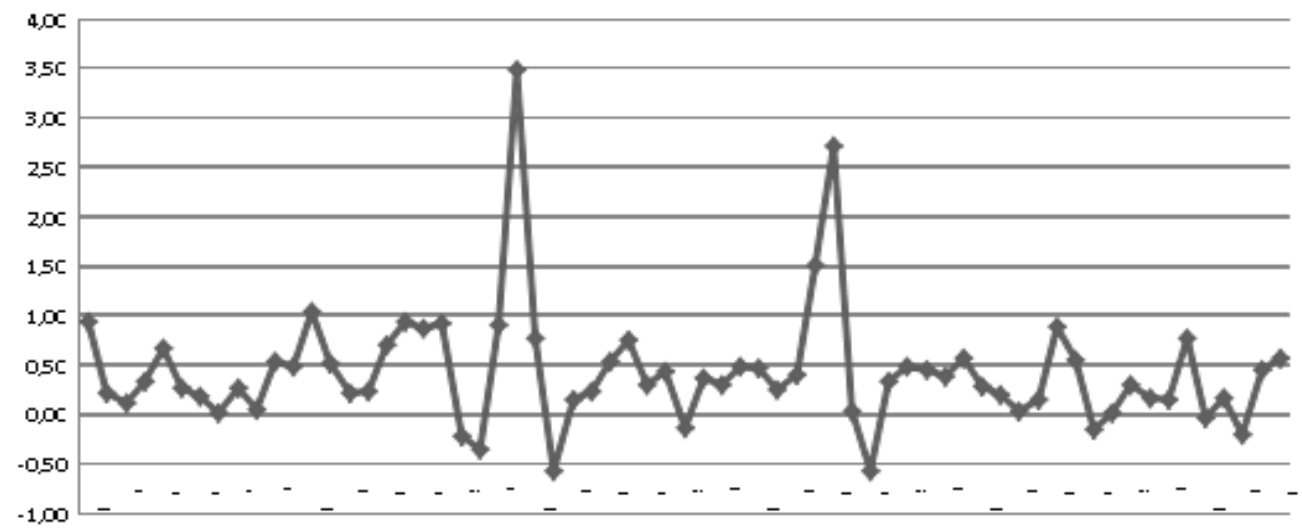

Sumber: Badan Statistik Kota Malang (2016) 


\section{METODE PENELITIAN}

Jenis penelitian ini adalah deskriptif kuantitatif. Studi deskriptif bertujuan untuk memperoleh deskriptif data yang mampu menggambarkan komposisi dan karakteristik dari unit yang diteliti dan data penelitian yang digunakan berupa angka-angka yang disesuaikan dengan tujuan penelitian. Jenis data yang digunakan dalam penelitian ini adalah data sekunder yang diperoleh dalam bentuk angka-angka dan analisisnya menggunakan statistik. Sumber data yang diperoleh dari instansi terkait permasalahan penelitian seperti BPS (Badan Pusat Statistik) dan SISKAPERBAPO (Sistem Informasi Ketersediaan dan Perkembangan Harga Bahan Pokok) Jawa Timur. Teknik yang digunakan dalam penelitian ini adalah dengan studi dokumentasi yang dilakukan dengan mengumpulkan data-data sekunder, mencatat, dan mengolah data yang berkaitan dengan penelitian ini. Alat analisis data yang digunakan adalah Partial Adjustment Model (PAM) dan Asumsi Klasik.

\section{PEMBAHASAN}

\section{A. Deskripsi data}

\section{Inflasi}

Inflasi merupakan suatu keadaan dimana terjadi kenaikan harga, yang bersifat umum dan terjadi secara terus menerus. Dalam kenaikan harga, harga suatu barang dapat dikatakan naik apabila harganya lebih tinggi dari harga yang sebelumnya.

Dalam penelitian ini digunakan data inflasi dari Indeks Harga Konsumen Kota Malang.

Tabel 1. Data Inflasi Kota Malang

\begin{tabular}{ccccccc}
\hline Bulan & $\mathbf{2 0 1 1}$ & $\mathbf{2 0 1 2}$ & $\mathbf{2 0 1 3}$ & $\mathbf{2 0 1 4}$ & $\mathbf{2 0 1 5}$ & $\mathbf{2 0 1 6}$ \\
\hline Januari & - & 0,27 & 0,94 & 0,76 & 0,04 & 0,56 \\
\hline Februari & - & 0,18 & 0,88 & 0,31 & $-0,57$ & $-0,15$ \\
\hline Maret & - & 0,01 & 0,93 & 0,43 & 0,34 & 0,02 \\
\hline April & - & 0,27 & $-0,21$ & $-0,13$ & 0,49 & 0,30 \\
\hline Mei & - & 0,05 & $-0,35$ & 0,37 & 0,45 & 0,17 \\
\hline Juni & - & 0,54 & 0,91 & 0,31 & 0,38 & 0,15 \\
\hline Juli & - & 0,48 & 3,49 & 0,49 & 0,57 & 0,78 \\
\hline Agustus & 0,94 & 1,04 & 0,77 & 0,47 & 0,28 & $-0,03$ \\
\hline September & 0,22 & 0,52 & $-0,57$ & 0,26 & 0,21 & 0,17 \\
\hline Oktober & 0,12 & 0,22 & 0,16 & 0,40 & 0,03 & $-0,20$ \\
\hline Nopember & 0,34 & 0,23 & 0,23 & 1,51 & 0,16 & 0,45 \\
\hline
\end{tabular}




\section{$\begin{array}{lllllll}\text { Desember } & 0,67 & 0,70 & 0,53 & 2,72 & 0,89 & 0,57\end{array}$}

Sumber: Badan Pusat Statistik Kota Malang (2016)

Pada tabel 1. dapat dilihat besaran inflasi periode Agustus 2011 sampai Desember 2016 menunjukkan besaran inflasi yang fluktuatif. Pada bulan Agustus tahun 2011 besaran inflasi tertinggi mencapai $0,94 \%$, tahun 2012 1,04\%. Hal ini dikarenakan pada bulan Agustus bertepatan dengan perayaan agama.

Besaran inflasi pada tahun 2013 tertinggi mencapai $3,49 \%$ dan pada tahun 2014 tertinggi mencapai 2,72\% hal ini disebabkan oleh perubahan harga Bahan Bakar Minyak (BBM) bersubsidi pada akhir bulan Juni sehingga berdampak sangat besar terhadap besarnya inflasi pada bulan Juli 2013. Pada tahun 2015 inflasi tertinggi mencapai 0,89 pada bulan
Desember dan pada tahun 2016 inflasi tertinggi mencapai $0,78 \%$ pada bulan Juli, hal ini dikarenakan bertepatan dengan perayaan keagamaan.

\section{Harga bawang merah}

Harga adalah suatu nilai tukar dari produk barang maupun jasa yang dinyatakan dalam satuan moneter.

Bawang merah merupakan salah satu komoditas yang memiliki fluktuasi harga yang relatif tinggi. Fluktuasi harga bawang merah dapat disebabkan oleh faktor permintaan dan penawaran.

Dalam penelitian ini digunakan harga komoditas Bawang merah dilihat dari sisi harga konsumen di Kota Malang.

Tabel 2. Data Harga Bawang Merah

\begin{tabular}{lcccccc}
\hline \multicolumn{1}{c}{ Bulan } & 2011 & 2012 & 2013 & 2014 & 2015 & 2016 \\
\hline Januari & - & 9410 & 15927 & 24350 & 20030 & 30993 \\
\hline Februari & - & 9583 & 17148 & 18246 & 16354 & 23090 \\
\hline Maret & - & 9459 & 39433 & 18600 & 25967 & 38060 \\
\hline April & - & 10093 & 38787 & 18067 & 28480 & 38473 \\
\hline Mei & - & 13483 & 28297 & 18623 & 29293 & 39327 \\
\hline Juni & - & 15207 & 23950 & 22643 & 26913 & 29253 \\
\hline Juli & - & 10007 & 42487 & 21893 & 21227 & 33327 \\
\hline Agustus & 11171 & 8370 & 43747 & 17643 & 15650 & 34810
\end{tabular}




\begin{tabular}{lrrrrrr}
\hline September & 10467 & 8400 & 26263 & 14207 & 14693 & 36693 \\
\hline Oktober & 10408 & 8620 & 23083 & 15095 & 15973 & 30993 \\
\hline Nopember & 10920 & 11270 & 27657 & 15273 & 16700 & 39277 \\
\hline Desember & 9085 & 13627 & 30726 & 17633 & 25563 & 35820
\end{tabular}

Sumber: Siskaperbapo Jawa Timur (2016)

Pada Tabel 2. dapat dilihat sehingga mengalami pengurangan besarnya harga Bawang merah jumlah hasil panen. Pada bulan Mei periode Agustus 2011 sampai 2016 harga Bawang merah tertinggi Desember 2016 menunjukkan harga mencapai Rp 39.327 hal ini yang berfluktuatif. Pada bulan dikarenakan terjadi shock demand Agustus tahun 2011 harga Bawang menjelang bulan Ramadhan. merah menunjukkan harga tertinggi mencapai $\mathrm{Rp} 11.171$ per $\mathrm{Kg}$ dikarenakan bertepatan dengan hari perayaan keagamaan.

Pada tahun 2013 terjadi kenaikan harga yang cukup tinggi pada bulan Agustus mencapai Rp 43.747 per $\mathrm{Kg}$, kenaikan tersebut akibat dari kenaikan harga Bahan Bakar Minyak (BBM) yang terjadi dari bulan Juli 2013.

Pada bulan Mei tahun 2015 harga bawang merah tertinggi mencapai Rp 29.293 hal ini dikarenakan petani Bawang merah

\section{Harga Cabe Rawit}

Harga adalah suatu nilai tukar dari produk barang maupun jasa yang dinyatakan dalam satuan moneter.

Cabe rawit merupakan salah satu komoditas yang memiliki fluktuasi harga yang relatif tinggi. Fluktuasi harga Cabai rawit dapat disebabkan oleh faktor permintaan dan penawaran.

Dalam penelitian ini digunakan harga komoditas Bawang merah dilihat dari sisi harga konsumen di Kota Malang. mengalami masalah gangguan hama

Tabel 3. Harga Cabe rawit

\begin{tabular}{lcccccc}
\hline \multicolumn{1}{c}{ Bulan } & 2011 & 2012 & 2013 & 2014 & 2015 & 2016 \\
\hline Januari & - & 16423 & 21630 & 30227 & 60103 & 29880 \\
\hline Februari & - & 16459 & 23007 & 43743 & 23456 & 17400 \\
\hline Maret & - & 28161 & 37180 & 64200 & 31155 & 47860 \\
\hline
\end{tabular}




\begin{tabular}{lcrrrrr}
\hline April & - & 33190 & 32967 & 48087 & 21700 & 22197 \\
\hline Mei & - & 10633 & 15317 & 14803 & 19560 & 18293 \\
\hline Juni & - & 12870 & 24640 & 11000 & 16587 & 17667 \\
\hline Juli & - & 14897 & 61430 & 9153 & 32030 & 34273 \\
\hline Agustus & 15286 & 17840 & 49197 & 15740 & 61113 & 41103 \\
\hline September & 13222 & 16497 & 28853 & 13347 & 49707 & 30873 \\
\hline Oktober & 13556 & 14833 & 36513 & 13587 & 15740 & 29433 \\
\hline Nopember & 17939 & 12773 & 21773 & 47750 & 15363 & 45853 \\
\hline Desember & 23680 & 11953 & 26170 & 85787 & 26633 & 51183 \\
\hline
\end{tabular}

Sumber: Siskaperbapo Jawa Timur (2016)

Pada Tabel 3. dapat dilihat besarnya harga Cabai rawit periode Agustus 2011 sampai Desember 2016 menunjukkan harga yang berfluktuatif. Pada tahun 2011 harga Cabe rawit menunjukkan harga tertinggi pada bulan Desember mencapai Rp 23.680, kenaikan harga diakibatkan pada bulan Desember terdapat perayaan hari keagamaan.

Pada tahun 2012 harga Cabai rawit tertinggi mencapai $\mathrm{Rp} 33.190$ pada bulan April, dikarenakan terjadi keterlambatan pasokan serta dampak dari dibatalkannya kebijakan pemerintah dalam merumuskan kebijakan kenaikan harga Bahan Bakar Minyak (BBM) sehingga berdampak pada ekspektasi distributor komoditas Cabai rawit.

Pada tahun 2013 harga Cabai rawit tertinggi mencapai $\mathrm{Rp} 61.430$ pada bulan Juli, hal ini dikarenakan dampak kenaikan harga Bahan Bakar
Minyak (BBM) dan bertepatan dengan perayaan hari keagamaan. Pada tahun 2014 harga Cabai rawit tertinggi mencapai $\mathrm{Rp} 85.787$ pada bulan Desember, hal ini dikarenakan faktor cuaca yang menyebabkan kegagalan panen serta kenaikan harga Bahan Bakar Minyak pada akhir bulan Novermber yang berimbas pada kenaikan harga yang tinggi.

Pada tahun 2016 harga Cabai rawit tertinggi mencapai $\mathrm{Rp} 51.183$, hal ini dikarenakan bertepatan dengan perayaan maulid nabi, hari natal dan liburan tahun baru.

\section{B. Analisis data}

\section{Hasil Uji Partial Adjustment} Model (PAM)

Pada Tabel.4 dapat disusun persamaan model dinamis autoregressive, dalam bentuk Partial Adjustment Model (PAM), Dimana hasil estimasi diatas merupakan 
estimasi jangka pendek yaitu sebagai

$$
\mathrm{Y}=0,348796+2,42 \mathrm{E}-05 X_{1 t}+
$$
berikut:

$2,16 \mathrm{E}-05 X_{2 t}+0,243979\left(\mathrm{Y}_{\mathrm{t}-1}\right) \quad-$

$2,69 \mathrm{E}-05\left(\mathrm{X}_{1 \mathrm{t}-1}\right)-2,12 \mathrm{E}-05\left(X_{2 \mathrm{t}-1}\right)$

Tabel 4. Uji Partial Adjustment Model (PAM)

\begin{tabular}{lcccc}
\hline \multicolumn{1}{c}{ Variabel } & Koefisien & Std. Error & t-statistik & Probabilitas \\
\hline C & 0.348796 & 0.155222 & 2.247078 & 0.0285 \\
\hline Bawang merah & $2.42 \mathrm{E}-05$ & $9.89 \mathrm{E}-06$ & 2.443978 & 0.0176 \\
\hline Cabe rawit & $2.16 \mathrm{E}-05$ & $4.41 \mathrm{E}-06$ & 4.907389 & 0.0000 \\
\hline Inflasi (-1) & 0.243979 & 0.101187 & 2.411161 & 0.0191 \\
\hline Bawang merah (-1) & $-2.69 \mathrm{E}-05$ & $9.87 \mathrm{E}-06$ & -2.731236 & 0.0083 \\
\hline Cabe rawit (-1) & $-2.12 \mathrm{E}-05$ & $4.49 \mathrm{E}-06$ & -4.712658 & 0.0000 \\
\hline
\end{tabular}

Sumber: Hasil Pengolahan Data (2017)

Dari persamaan hasil estimasi

autoregressive Partial Adjustment

Model (PAM) maka dapat dianalisis

sebagai berikut:

a. Intercept atau konstanta bernilai positif 0,348796, hal ini menunjukkan bahwa jika variabel harga bawang merah, cabe rawit dan inflasi sebelumnya konstan maka inflasi bernilai 0,348796 .

b. Koefisien bawang merah adalah 2,42E-05 hal ini berarti bahwa setiap kenaikan harga bawang merah sebesar $1 \%$ maka akan menyebabkan perubahan inflasi sebesar 0,0000242\% , dengan anggapan variabel lain dianggap konstan.

c. Koefisien cabe rawit adalah 2,16E-05 hal ini berarti bahwa setiap kenaikan harga cabe rawit sebesar $1 \%$ maka akan menyebabkan perubahan inflasi sebesar 0,0000216\%, dengan anggapan variabel lain dianggap konstan.

d. Koefisien inflasi sebelumnya adalah sebesar 0,243979, hal ini berarti bahwa setiap perubahan inflasi sebelumnya sebesar $1 \%$ menyebabkan perubahan inflasi sebesar $0.243979 \%$, dengan variabel bebas lainnya dianggap konstan.

e. Koefisien bawang merah sebelumnya adalah -2,69E-05, hal ini berarti bahwa setiap perubahan harga bawang merah sebelumnya sebesar $1 \%$ maka akan menyebabkan perubahan inflasi sebesar $-0,0000269 \%$, 
dengan variabel bebas lainnya dianggap konstan.

f. Koefisien cabe rawit sebelumnya adalah -2,12E-05, hal ini berarti bahwa setiap perubahan harga cabe rawit sebelumnya sebesar 1\% maka akan menyebabkan perubahan inflasi sebesar $0,0000212 \%$, dengan variabel bebas lainnya dianggap konstan.
Dengan adanya kelambanan, maka untuk hasil estimasi jangka panjang dari estimasi Partial Adjustment Model (PAM) yaitu sebagai berikut:

$$
Y=0,461357+3,2 \mathrm{E}_{0} 5 \mathrm{X}_{1 \mathrm{t}}+2,86 \mathrm{E} 05 \mathrm{X}_{2 \mathrm{t}}
$$

Hasil di atas dapat dilihat dari hasil perhitungan tabel sebagai berikut:

Tabel 5. Hasil Estimasi jangka pendek dan jangka panjang

\begin{tabular}{lcc}
\hline \multicolumn{1}{c}{ Variabel } & \multicolumn{2}{c}{ Pengaruh } \\
\cline { 2 - 3 } C & Jangka Pendek & Jangka Panjang \\
\hline Bawang merah & $\alpha_{0}=0,348796$ & $\alpha_{0}=\frac{\alpha_{0}}{1-\alpha_{3}}=0,461357$ \\
\hline Cabe rawit & $\alpha_{1}=2,42 \mathrm{E}-05$ & $\alpha_{1}=\frac{\alpha_{1}}{1-\alpha_{3}}=3,2 \mathrm{E}-05$ \\
\hline Inflasi(-1) & $\alpha_{2}=2,16 \mathrm{E}-05$ & $\alpha_{2}=\frac{\alpha_{2}}{1-\alpha_{3}}=2,86 \mathrm{E}-05$ \\
\hline Bawang merah(-1) & $\alpha_{3}=0,243979$ & \\
\hline Cabe rawit(-1) & $\alpha_{5}=-2,69 \mathrm{E}-05$ & \\
\hline Sumber: Hasil Pengo & $\alpha_{5}=-2,12 \mathrm{E}-05$ & \\
\hline
\end{tabular}

Sumber: Hasil Pengolahan Data (2017)

Untuk penyesuaian jangka Sebaliknya jika harga cabe rawit panjang, yaitu berdasarkan turun $1 \%$, maka inflasi juga akan perhitungan penyesuaian pada Tabel 5. dapat dijelaskan bahwa apabila harga bawang merah naik $1 \%$, maka inflasi akan naik sebesar 0,000032\%. Sebaliknya apabila harga bawang merah turun sebesar $1 \%$, maka inflasi turun sebesar 0,000032\%. Apabila harga cabe rawit naik $1 \%$ maka inflasi turun sebesar $0,0000286 \%$.

\section{Hasil Uji Asumsi Klasik}

\section{Uji Normalitas}

Dari hasil analisis diperoleh pvalue statistik uji Jarque-Bera sebesar 0.153684. nilai tersebut lebih besar dari $\alpha=0,05$, sehingga diputuskan $H_{0}$ diterima. Dengan demikian dapat akan naik sebesar $0,0000286 \%$. 
disimpulkan bahwa normalitas antar variabel independen dibawah error/residual terpenuhi.

\section{Uji Multikoliniearitas}

0,80 dengan demikian data dalam

Dari Tabel 9. dapat dilihat penelitian ini tidak terjadi masalah bahwa nilai koefisien korelasinya multikoliniearitas.

Tabel 9. Hasil Uji Multikoliniearitas Inflasi Bawang Merah Cabe rawit

\begin{tabular}{lccc}
\hline Inflasi & - & 0.099750 & 0.398355 \\
\hline Bawang merah & 0.099750 & - & 0.339714 \\
\hline Cabe rawit & 0.398355 & 0.339714 & -
\end{tabular}

Sumber: Hasil Pengolahan Data (2017)

\section{Uji Heteroskedastisitas}

Berdasarkan hasil uji ARCH diperoleh nilai Prob. Chi-square = 0.9312 yang mana lebih besar dari $\alpha$ $=0,05$, sehingga diputuskan gagal tolak H0. Dengan demikian dapat disimpulkan bahwa asumsi nonheteroskedastisitas terpenuhi.

\section{Uji Autokorelasi}

Hasil uji Durbin Watson dapat dilihat pada Tabel 10. nilai DurbinWatson 1,7318 terletak diantara dU sebesar 1,6621 dan 4-dU sebesar 2.3379 yang dapat ditulis seperti $d U<d<4-d U$ sehingga dapat disimpulkan tidak terjadi masalah autokorelasi dalam data.

Tabel 10. Hasil Uji Autokorelasi

\begin{tabular}{cc}
\hline Durbin-Watson statistik & Durbin-Watson tabel \\
\hline $\mathbf{1 , 7 3 1 8}$ & $\mathrm{dL}=1,5355$ \\
\hline & $\mathrm{dU}=16621$ \\
\hline & $4-\mathrm{dU}=2,3379$ \\
\hline & $4-\mathrm{dL}=2,8464$
\end{tabular}

Sumber: Hasil Pengolahan Data (2017)

\section{Jangka Panjang}

Pada penyesuaian jangka panjang variabel harga bawang merah berpengaruh signifikan, dijelaskan bahwa apabila harga bawang merah naik $1 \%$, maka inflasi akan naik sebesar 0,000032\%. Sebaliknya apabila harga bawang merah turun sebesar $1 \%$, maka inflasi turun sebesar $0,000032 \%$. 
Pada penyesuaian jangka panjang variabel cabe rawit berpengaruh signifikan, dijelaskan bhawa apabila harga cabe rawit naik $1 \%$ maka inflasi akan naik sebesar $0,0000286 \%$. Sebaliknya jika harga cabe rawit turun 1\%, maka inflasi juga akan turun sebesar 0,0000286\%.

\section{Jangka Pendek}

Pada persamaan jangka pendek nilai variabel bawang merah adalah 2,42E-05 hal ini berarti bahwa setiap kenaikan harga bawang merah sebesar $1 \%$ maka akan menyebabkan perubahan inflasi sebesar 0,0000242\%, dengan anggapan variabel lain dianggap konstan.inflasi $(Y)$ sebesar 2,29E-05 persen, dengan asumsi variabel lain dianggap konstan.

Pada persamaan jangka pendek nilai variabel cabe rawit adalah 2,16E-05 hal ini berarti bahwa setiap kenaikan harga cabe rawit sebesar $1 \%$ maka akan menyebabkan perubahan inflasi sebesar 0,0000216\%, dengan anggapan variabel lain dianggap konstan.

\section{PENUTUP}

\section{Kesimpulan}

Harga komoditas pangan merupakan salah satu penyumbang inflasi di Kota Malang. Distribusi penawaran dan permintaan yang tidak stabil menyebabkan harga komoditas pangan sering mengalami fluktuasi. Ketika produksi bahan pokok mengalami gagal panen akibat cuaca, gangguan hama, serta faktor perkembangan harga bahan pokok akan mengganggu jalannya distribusi dan mengakibatkan cost push inflation. Sementara dari sisi permintaan akan mengakibatkan demand pull inflation karena tingginya permintaan terhadap barang pokok. Namun tingginya permintaan tersebut relatif terhadap ketersediaannya sehingga akan menciptakan kejutan harga yang cenderung naik yang nantinya akan berpengaruh terhadap besarnya inflasi. Bawang merah dan cabe rawit merupakan dua komoditas pangan yang sering mengalami fluktuasi harga dan berdampak pada besarnya inflasi. Sesuai dengan hasil analisis, Pada penyesuaian jangka panjang, dijelaskan bahwa apabila 
harga bawang merah naik 1\%, maka inflasi akan naik sebesar 0,000032\%. Sebaliknya apabila harga bawang Pada penyesuaian jangka panjang, dijelaskan bahwa apabila harga cabe rawit naik $1 \%$ maka inflasi akan naik sebesar $0,0000286 \%$. Sebaliknya jika harga cabe rawit turun $1 \%$, maka inflasi juga akan turun sebesar 0,0000286\%.

Pada persamaan jangka pendek nilai variabel bawang merah adalah 2,42E-05 hal ini berarti bahwa setiap kenaikan harga bawang merah sebesar $1 \%$ maka akan menyebabkan perubahan inflasi sebesar 0,0000242\% , dengan anggapan variabel lain dianggap konstan. Pada persamaan jangka pendek nilai variabel cabe rawit adalah 2,16E-05 hal ini berarti bahwa setiap kenaikan harga cabe rawit sebesar $1 \%$ maka akan menyebabkan perubahan inflasi sebesar 0,0000216\%, dengan anggapan variabel lain dianggap konstan.

\section{Saran}

Pemerintah pusat harus bekerjasama dengan pemerintah daerah tempat sentra produksi bawang merah dan cabe rawit agar merah turun sebesar $1 \%$, maka inflasi turun sebesar $0,000032 \%$.

menerapkan pola tanam jenis komoditas tersebut guna mengurangi produksi yang berlebihan pada musim panen tiba. Disamping itu perlu penanaman di luar musim agar defisit kedua komoditas tidak terlalu besar sehingga harga akan cukup stabil dan tidak berdampak besar terhadap besarnya inflasi.

Perbaikan sistem tata niaga atau distribusi dengan menerapkan supply chain management akan membuat kedua jenis komoditas menjadi lebih efisien. Perbaikan logistik dan pasca panen memungkinkan kedua komoditas tersedia bagi konsumen tepat waktu dan bahkan dapat disalurkan di luar musim panen.

\section{DAFTAR PUSTAKA}

Badan Pusat Statistik Kota Malang, 2016. Data Inflasi Tahun 20112016. Kota Malang. https://malangkota.bps.go.id/. [Diakses pada 12 Desember 2016].

Kementerian Pertanian, 2016. Data Luas Lahan Pertanian Di Kota 
Pengaruh Harga Komoditas Pangan Terhadap Inflasi ...... (Dicky Zunifar R.)

Malang. http://pertanian.go.id/. [Diakses pada 12 April 2017] Prabowo, Dwi Wahyuniarti. 2014. Pengelompokan Komoditi Bahan Pangan Pokok Dengan Metode Analitycal Hierarchy Process. Jurnal Ilmiah: Pusat Kebijakan Perdagangan Dalam Negeri. Jakarta Pusat. Santoso, Teguh. 2011. "Aplikasi Model GARCH pada Data Inflasi Bahan Makanan Indonesia. Jurnal Organisasi dan Manajemen", Vol. 7, Nomor 1, hlm: 38-52.
Siskaperbapo Jawa Timur. 2016. Harga Komoditas Bawang merah dan Cabe rawit KotaMalang Tahun 2011-2016. Http://siskaperbapo.com/harga/ grafik [Diakses pada 12 Desember 2016].

Sumaryanto. 2009. "Analisis Volatilitas Harga Eceran Beberapa Komoditas Pangan Utama dengan Model ARCH/GARCH". Jurnal Agro Ekonomi, Vol. 27, No. 2, hlm: 135-16. 